\title{
COVID-19 Pandemi Döneminde Toplu Beslenme Servisi Yapan Farklı Kurumların Menülerinin Değerlendirilmesi
}

\author{
Evaluation of the Menus of Food Service Systems of Different Institutions During COVID-19 \\ Pandemic
}

\author{
Sümeyra Sevim , Damla Gümüş², Gülsüm Gizem Topal², Mevlüde Kızıl ${ }^{4}$
}

Geliş tarihi/Received: 04.06.2021 • Kabul tarihi/Accepted: 05.10.2021

\section{ÖZET}

Amaç: COVID-19 pandemisi sırasında uygulanan kısıtlamalar eğitim, mesai uygulamaları, sosyal etkinlikler gibi birçok alanda olduğu gibi toplu beslenme hizmetlerini de etkilemiştir. Virüsün yayılımının engellenmesi amacıyla toplu beslenme sistemleri (TBS)’nde çeşitli önlemler geliştirilmiş ve bu önlemler kapsamında bazı kurumlarda masaya servis yerine kumanya menüler servis edilmiştir. Bu çalışma, pandemi döneminde Ankara’da hizmet veren farklı TBS’ye ait menü türlerinin incelenmesi amacıyla gerçekleştirilmiştir.

Gereç ve Yöntem: Çalışmada tek öğün toplu beslenme hizmeti veren üç farklı kurumun (kamu, özel ve yarı özel) iki farklı menü tipi (kumanya ve normal) incelenmiş, menülerin enerji, makro ve mikro besin ögesi içerikleri Türkiye Beslenme Rehberi (TÜBER)'nde önerilen enerji ve besin ögesi gereksinimlerine göre yeterlilik yönünden değerlendirilmiştir. Menülerin besin ögesi örüntüsü Besin Ögesinden Yoğun Besin (NRF) 9.3 ile hesaplanarak incelenmiştir.

Bulgular: Menüler arasında en yüksek NRF9.3 puanı (85.7×18.9) kamu kuruluşunun normal menüsünde, en düşük NRF9.3

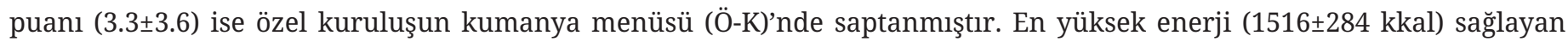

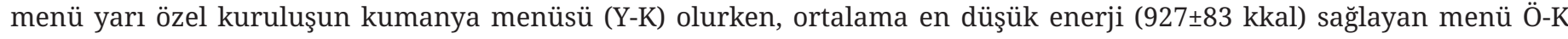
olmuştur. Ö-K erkekler için enerji; her iki cinsiyet için protein ve lif gereksinmesini karşllamada yetersiz bulunmuştur. Diğer tüm menülerde ise bu besin ögelerinin gereksinimleri karşıladığı tespit edilmiştir.

Sonuç: Bireylerin yeterli ve dengeli beslenmesine katkı sağlamak ve bağışıklık sistemi fonksiyonlarını desteklemek için TBS’de sunulan menülerin, kumanya menüsü gibi farklı servis türleri dahil olmak üzere tüketicilerin enerji ve besin ögesi gereksinmelerini karşılayacak, zengin besin ögesi örüntüsüne ve yüksek diyet kalitesine sahip olması sağlanmalı ve dolayısıyla kurumlarda diyetisyen istihdamının gerekliliği göz ardı edilmemelidir.

Anahtar kelimeler: COVID-19, toplu beslenme, menü, besin ögesi örüntü profili
ABSTRACT
Aim: The restrictions applied during the COVID-19 pandemic have affected food service systems (FSS) as well as many areas such as education, working hours, and social events. Within the scope of measures for preventing the transmission of the

\footnotetext{
1. İletişim/Correspondence: Hacettepe Üniversitesi, Sağlık Bilimleri Fakültesi, Beslenme ve Diyetetik Bölümü, Türkiye

E-posta: sumeyrasevim@hacettepe.edu.tr - 이 https://orcid.org/0000-0001-9724-2628

2. Hacettepe Üniversitesi, Sağlık Bilimleri Fakültesi, Beslenme ve Diyetetik Bölümü, Türkiye • (ㄱ) https://orcid.org/0000-0002-3099-3432
}
3. Hacettepe Üniversitesi, Sağlık Bilimleri Fakültesi, Beslenme ve Diyetetik Bölümü, Türkiye • (1) https://orcid.org/0000-0002-3959-0808
4. Hacettepe Üniversitesi, Sağlık Bilimleri Fakültesi, Beslenme ve Diyetetik Bölümü, Türkiye • (1) https://orcid.org/0000-0003-1380-3243 
virus, take away-lunch box menus were served instead of table service of normal menus in FSS. This study was carried out to examine the menu types of different FSS of institutions in Ankara during the pandemic period.

Subjects and Method: In the study, two different menus (lunch box and normal) of three different institutions which serve one meal a day food service (public, private and semi- private) were examined, and the energy, macro, and micronutrient contents of the menus were evaluated in terms of adequacy according to the Turkey Nutrition Guide (TUBER). The nutrient profile of the menus was examined with the Nutrient Rich Nutrient Index (NRF) 9.3.

Results: The highest NRF9.3 score $(85.7 \pm 18.9)$ was found in the normal menu of the public institution, and the lowest NRF9.3 score (3.3 \pm 3.6$)$ was found in the lunch box of the private institution across all the menus. The menu providing the highest energy $(1516 \pm 284 \mathrm{kcal})$ was the normal menu of the semi-private institution, while the lowest average energy $(927 \pm 83$ $\mathrm{kcal}$ ) was found in the lunch box of private institution. The lunch box in private institutions were insufficient in terms of meeting energy requirements for men, and protein and fiber requirements for both genders. It has been determined that the requirements of these nutrients were met in all other menus.

Conclusion: In order to contribute to the adequate and balanced nutrition of individuals and to support the immune system functions, it should be ensured that the menus presented in FSS, including different service types such as lunch box, meet the energy and nutrient requirements of the consumers, have a rich nutrient profile and high diet quality. Therefore, the necessity of employing dietitians in institutions should not be ignored.

Keywords: COVID-19, food service, menu, nutrient profiling

\section{GİRIş}

Koronavirüs hastalığı (COVID-19) 2019 yllının sonunda ortaya çıkışından günümüze dek hızlı bulaşıcılığı ile tüm dünyayı etkisi altına almış, Dünya Sağlık Örgütü (DSÖ) Mart 2020'de şiddetli akut solunum sendromu koronavirüsün (SARS-CoV-2) neden olduğu bu hastalığı pandemi ilan etmiştir (1,2). Pandemi sürecinde virüsün yayılmasını durdurmak amacıyla geliştirilen önlemler tüm dünyada olduğu gibi Türkiye'de de uygulanmıştır (3). İçişleri Bakanlığı'nın ilgili Genelgelerinde Koronavirüs salgınıyla mücadele amacıyla çeşitli tedbirler alınmış ve Sağlık Bakanlığı tarafindan "Salgın Yönetimi ve Çalışma Rehberi” yayınlanmıştır $(4,5)$. Buna göre insanların toplu şekilde bir araya gelmesini önlemek için restoran, kafe gibi beslenme hizmeti verilen TBS'de, kurumlarin sadece paket servis hizmetine izin verilerek faaliyetlerine kısıtlama getirilmiştir (6). Uzaktan çalışmaya geçmeyen kurumlarda çalışan bireylerin iş yerinde bulundukları süre içerisinde toplu beslenme hizmetlerinden yararlanabilmesi için ise bu kurumlarda yemek ve içeceklerin mümkünse kumanya şeklinde dağıtılması, yemekhanede masalar ve sandalyeler arası mesafenin en az 1.5 metre olacak şekilde (tercihen 2 metre) düzenlenmesi, 4 kişilik bir masada tercihen 1 en fazla 2 kişinin çapraz şekilde oturması gibi çeşitli uygulamalar yapılmıştır (5).

Bugüne dek besinlerin koronavirüsün bulaşmasına neden olduğuna ilişkin herhangi bir rapor bulunmamakla birlikte, virüs enfekte kişiler aracılığıyla besinleri, ambalajlarını ve servis gereçlerini kontamine edebilmektedir. $\mathrm{Bu}$ nedenle TBS'de yiyecek akışı boyunca besinleri depolama, işleme, hazırlama, pişirme, paketleme, servis ve teslimat basamaklarında önlemler alınması önem taşımaktadır $(7,8)$. Ayrıca, yüz yüze iletişim kurulduğunda koronavirüsün solunum damlacıkları yoluyla yayllabileceği düşünüldüğünde, TBS’de yemek yiyen tüketiciler için COVID-19 yönünden riskler oluşabilmektedir. Bu nedenle, maske takılması, yemekhanelerde doluluk oranının kapasitenin yarısına düşürülmesi, sosyal mesafenin sürdürülmesi, tüketiciler için el dezenfektanı bulundurulması, personelin izlenmesi ve denetlenmesi, tüm alanlarda yeterli havalandırmanın sağlanması gibi kurallara uyulması gerekmektedir $(9,10)$. 
Beslenmenin bağışıklık sistemi üzerindeki etkisi uzun süredir bilinmektedir. Çok sayıda bilimsel çalışma, bağışıklık sistemi hücreleri dahil olmak üzere tüm hücrelerin en iyi şekilde fonksiyon göstermesi için yeterli ve dengeli beslenmenin gerekli olduğunu göstermektedir (1,11,12). Bu nedenle, pandemi döneminde uygulanabilecek en iyi beslenme şeklinin günlük enerji gereksinmesini karşılayan, bağışıklık sistemi fonksiyonlarını destekleyen makro ve mikro besin ögeleri yönünden yeterli, besin grupları yönünden çeşitli ve dengeli bir diyet olduğu bildirilmektedir (1).

Pandemi önlemleri kapsamında birçok kurumda masaya servis yerine kumanya menüler servis edildiği bilinmekle birlikte, literatürde bu menülerin incelendiği bir çalışma bulunmamaktadır. $\mathrm{Bu}$ kapsamda bu çalışma, Ankara'da hizmet veren üç farklı yapıda kurumun COVID-19 pandemi döneminde TBS'de sundukları menülerin enerji, besin ögesi ve diyet kalitesi yönünden değerlendirilmesi amacıyla gerçekleştirilmiştir.

\section{GEREÇ VE YÖNTEM}

Bu çalışmada, Ankara’da çalışanlarına tek öğün toplu beslenme hizmeti sunan üç farklı nitelikte kurumun (Kamu-K, Özel-Ö, Yarı Kamu Yarı Özel-Y) 2020 yılı Aralık ayında sunmuş oldukları set seçimsiz normal
(N) menüler (2 haftalık) ile kumanya (K) menüleri (2 haftalık) incelenerek karşılaştırılmıştır. Kumanya menüleri, Koronavirüs Ek Tedbirleri (04.11.2020) kapsaminda kafeterya gibi yeme içme yerlerinde masaya servisin kapatılması nedeniyle kurumlarda öğle yemeğinde paketli olarak sunulan menülerdir.

Kurumlarda sunulan menülerin içerikleri Tablo 1'de verilmiştir. Ayrıca kumanya menülerinde servis edilen yemek ve besin gruplarından bazı örnekler Ek 1'de verilmiştir.

\section{Menülerin Enerji ve Besin Ögesi İçeriklerinin Belirlenmesi}

Amerikan Gıda ve İlaç Kurumu (Food and Drug Administration-FDA)'nun menü etiketine yönelik yayınladığı kurallara göre etikette bulunması gereken enerji ve besin ögesi içeriklerinin [Protein, karbonhidrat, yağ, doymuş yă̆ asitleri (y.a.), kolesterol, lif, eklenmiş şeker, sodyum (Na)] belirlenmesi için TBS'de kullanılan standart yemek tarifeleri kullanılmıştır $(13,14)$. Bu tarifelere göre menülerde yer alan yemeklerin bir porsiyonunun içerikleri Beslenme Bilgi Sistemi (BEBİs) 8.2 programı ile hesaplanmıştır. Hesaplamalara servis edilen bir yuvarlak beyaz ekmek (50 gram) ve standart tarifelerde belirtilen tuz miktarları dahil edilmiştir.

Tablo 1. Kurumlarda sunulan menülerin içerikleri

\begin{tabular}{|c|c|c|}
\hline & Normal (N) & Kumanya (K) \\
\hline Kamu Kuruluşu (K) & $\begin{array}{l}\text { - Çorba } \\
\text { - 1.Kap yemek } \\
\text { - 2.Kap yemek } \\
\text { - 3.Kap yemek }\end{array}$ & $\begin{array}{l}\text { - 1.Kap yemek } \\
\text { - 3.Kap yemek } \\
\text { - 3.Kap yemek }\end{array}$ \\
\hline Özel Kuruluş (Ö) & $\begin{array}{l}\text { - 1.Kap yemek } \\
\text { - 2.Kap yemek } \\
\text { - 2. veya 3.Kap yemek } \\
\text { - 3.Kap yemek }\end{array}$ & - 7 farklı besin \\
\hline Yarı kamu yarı özel (Y) & $\begin{array}{l}\text { - Çorba } \\
\text { - 1.Kap yemek } \\
\text { - 2.Kap yemek } \\
\text { - 2. veya 3.Kap yemek } \\
\text { - 3.Kap yemek (İçecek) } \\
\text { - 3.Kap yemek (Tatll) }\end{array}$ & $\begin{array}{l}\text { - Çorba } \\
\text { - 1.Kap yemek } \\
\text { - 2.Kap yemek } \\
\text { - 2. veya 3.Kap yemek } \\
\text { - 3.Kap yemek } \\
\text { - 3.Kap yemek }\end{array}$ \\
\hline
\end{tabular}




\section{Menülerin Gereksinimleri Karşılama Yönünden Değerlendirilmesi}

Menülerin personelin günlük enerji ve besin ögesi gereksinmelerini karşılama yeterliliğinin değerlendirilmesinde günlük ortalama enerji, protein, karbonhidrat, yağ, kolesterol, lif ve $\mathrm{Na}$ gereksinim miktarları için TÜBER (15), doymuş y.a. ve eklenmiş şeker miktarı için Avrupa Gıda Güvenliği Otoritesi (European Food Safety Authority-EFSA) (16) referans alınmıştır. Kurumlar tek öğün yemek hizmeti verdiğinden dolayı menülerin içeriğinin 19-50 yaş arası, orta aktif grup erkek ve kadın bireyler için belirlenen referans değerlerinin 2/5'ini karşılaması yeterli kabul edilmiştir (17).

\section{Menülerin Besin Ögesi Örüntü Profiline Göre Değerlendirilmesi}

Menülerin besin ögesi yoğunluğunu ölçmek ve değerlendirmek için Drewnowski et al. (18) tarafindan geliştirilmiş besin ögesi örüntü profili değerlendirme modeline dayanan Besin Ögesinden Yoğun Besin (NRF) 9.3 puanları hesaplanmıştır. Bu hesaplamaya göre diyetle alımı önerilen dokuz besin ögesinin (Protein, lif, A, C ve E vitamini, kalsiyum, demir, potasyum ve magnezyum) günlük değerlerinin yüzde cinsinden toplamı pozitif alt skor (NRF9), diyetle alımı sınırlandırılması önerilen üç besin ögesinin (Doymuş y.a., Na ve eklenmiş şeker) günlük değerlerinin yüzde cinsinden toplamı negatif alt skor (NRF3) olarak hesaplanmış ve pozitif alt skordan negatif alt skorun çıkartılması ile son skor saptanmıştır. Hesaplamada besinler $100 \mathrm{kkal}$ enerji veren miktarlarına göre değerlendirilmiştir (18,19). Elde edilen NRF9.3 puanları arttıkça, 100 kkal başına düşen besin yoğunluğunun arttığı belirtilmektedir. Bu nedenle yüksek NRF9.3 puanı, düşük NRF9.3 puanına göre daha sağlıklı bir beslenme düzenini temsil etmektedir (20).

NFR9.3 skorunun hesaplanmasinda kullanilan besin ögelerinin günlük ortalama gereksinim miktarları için 19-50 yaş arası, orta aktif grup erkek ve kadın bireylere özgü Türkiye için belirlenen gereksinimler referans alınmıştır (15). Türkiye'ye özgü günlük ortalama gereksinimi belirtilmeyen besin ögeleri için EFSA'nın belirlediği miktarlar referans alınmıştır (16).

\section{Verilerin İstatistiksel Değerlendirmesi}

Verilerin istatistiksel değerlendirmesinde SPSS 25.0 programı kullanılmıştır. Menülerin enerji ve besin ögesi içerikleri ve NRF9.3 puanları ortalama $(\overline{\mathbf{x}})$ ve standart sapma (S) olarak verilmiştir. Menülerin enerji, besin ögesi ve NRF puanlarındaki kurumlar arası farklılığın istatistiksel değerlendirilmesinde ANOVA testi kullanılmış, gruplar arası farklılık Tukey testi ile belirlenmiştir. Kurumların farklı menülerinin istatistiksel karşılaştırılmasında bağımsız gruplar-t testi kullanılmıştır. $\mathrm{p}<0.05$ değeri istatistiksel olarak anlamlı kabul edilmiştir.

\section{BULGULAR}

Menülerin NFR9.3 skorları ile ortalama enerji ve makro/mikro besin ögesi içerikleri Tablo 2'de verilmiştir. En yüksek NRF9.3 puanı (85.7 \pm 18.9$)$ K-N'de, en düşük NRF9.3 puanı $(3.3 \pm 3.6)$ ise Ö-K'da tespit edilmiştir. Bununla birlikte menülerin NRF9.3 puanları K-K ve K-N'de benzerken $(\mathrm{p}<0.05)$, Ö-N'nin Ö-K'dan; Y-N'nin Y-K'dan anlamlı düzeyde yüksek bulunmuştur $(\mathrm{p}<0.05)$. Ayrıca $\mathrm{K}-\mathrm{K}$, Ö-K ve Y-K'nın NRF9.3 puanları benzerken ( $p<0.05)$, Ö-N'nin NRF9.3 puanı K-N ve Y-N'nin puanından düşük bulunmuştur $(\mathrm{p}<0.05)$.

Benzer şekilde en yüksek NRF9 puanı K-N'de, en düşük NRF9 puanı Ö-K'da bulunmuştur. Kumanya menülerinin NRF9 puanları da benzer bulunurken ( $p>0.05$ ), Ö-K'nın NRF9 puanı K-K ve Y-K'nın puanından düşük bulunmuştur ( $\mathrm{p}<0.05)$. Bu durumun aksine en yüksek NRF3 puanı Ö-K'da, en düşük NRF3 puanı K-K'da elde edilmiştir. Ö-K'nın NRF3 puanı (26.3 \pm 1.09$)$, $\mathrm{K}-\mathrm{K}$ ve Y-K'nın puanından yüksek bulunurken $(p<0.05)$, normal menülerin NRF3 puanları benzer bulunmuştur ( $\mathrm{p}>0.05)$.

Menüler arasında en yüksek enerji (1516ェ284 kkal) sağlayan menü Y-K olurken, ortalama en düşük 


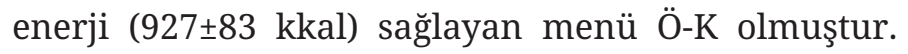
K-K ve K-N'nin, Y-K ve Y-N'nin ortalama enerji içerikleri benzerken ( $\mathrm{p}<0.05)$, Ö-K’nın enerji içeriği Ö-N'den anlamlı düzeyde düşük bulunmuştur $(p<0.05)$. TÜBER'e göre yetişkin bireyler için enerjinin proteinden gelen oraninin kadınlarda \%12-20, erkeklerde \%10-20 arasında, karbonhidrattan gelen oranının \%45-60 ve yağdan gelen oranının \%20-35 olması gerektiği belirtilmektedir (15). Menülerin enerji değerinin karbonhidrattan sağlanan oranı istenilen aralık içerisindeyken, proteinden sağlanan oranı Ö-K’da olması gereken aralığın altında, yağdan sağlanan oranın ise $\mathrm{K}-\mathrm{K}$ ve $\mathrm{Y}-\mathrm{K}$ haricinde olması gereken aralığın üzerinde olduğu tespit edilmiştir (Şekil 1).

Tüm kumanya ve normal menülerde enerjinin doymuş y.a.'dan sağlanan oranı önerilen aralığın (\%78) üzerinde bulunurken, eklenmiş şekerden sağlanan oranı günlük tüketilmesi önerilen maksimum miktarın (\%10) altında bulunmuştur.

K-K ile K-N'nin ve Y-K ile Y-N'nin lif içerikleri benzer

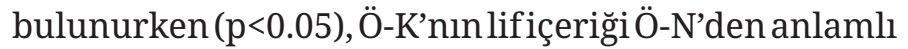
düzeyde düşük bulunmuştur ( $\mathrm{p}<0.01)$. K-K ve Ö-K’nın
Na içerikleri aynı kurumun normal menülerinden anlamlı düzeyde düşük bulunurken $(\mathrm{p}<0.05), \mathrm{Y}-\mathrm{K}$ ve Y-N'nin Na içerikleri benzer bulunmuştur ( $p>0.05$ ).

K-K'nın kolesterol içeriği K-N'den önemli düzeyde yüksek bulunurken $(\mathrm{p}<0.05)$, diğer menülerin kolesterol içeriği benzer bulunmuştur $(\mathrm{p}<0.05)$. Ayrıca tüm menülerin eklenmiş şeker içerikleri benzerdir $(\mathrm{p}>0.05)$.

Menülerin ortalama enerji ve besin ögesi içeriklerinin erkek ve kadınlarda günlük ortalama gereksinimleri karşılama yüzdeleri Tablo 3’te verilmiştir. Y-K ve Y-N, her iki cinsiyette de günlük enerji, makro ve mikro besin ögeleri gereksinimlerinin 2/5'inden fazlasını karşılamaktadır. Ancak bu kurumun menülerinin doymuş y.a. içeriği önerilen üst limitin yaklaşık iki katı, Na içeriği ise önerilen miktarın iki katından fazla bulunmuştur. Protein gereksinimini karşlama yönünden menüler incelendiğinde, sadece Ö-K’nın erkek ve kadınlarda gereksinimin 2/5'ini karşılamada yetersiz olduğu saptanmıştır (sırasıyla $\% 59.7 \pm 7.8$ ve \%68.0 \pm 8.9 ). Benzer şekilde Ö-K, lif gereksinmesini karşılama bakımından da yetersiz bulunmuştur.

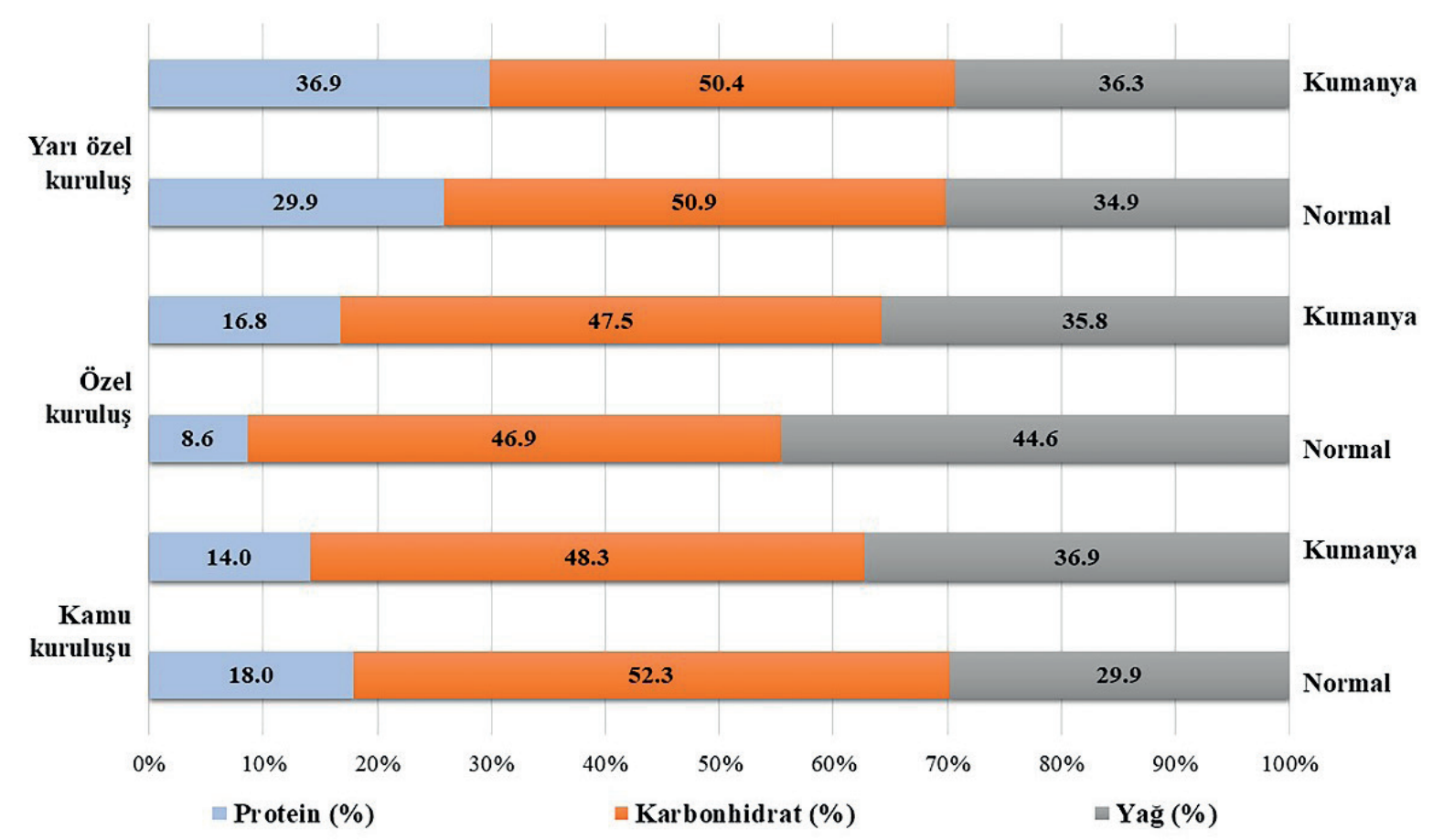

Şekil 1. Farklı kuruluşların kumanya ve normal menülerinin ortalama enerjinin makro besin öğelerinden gelen yüzdesi 


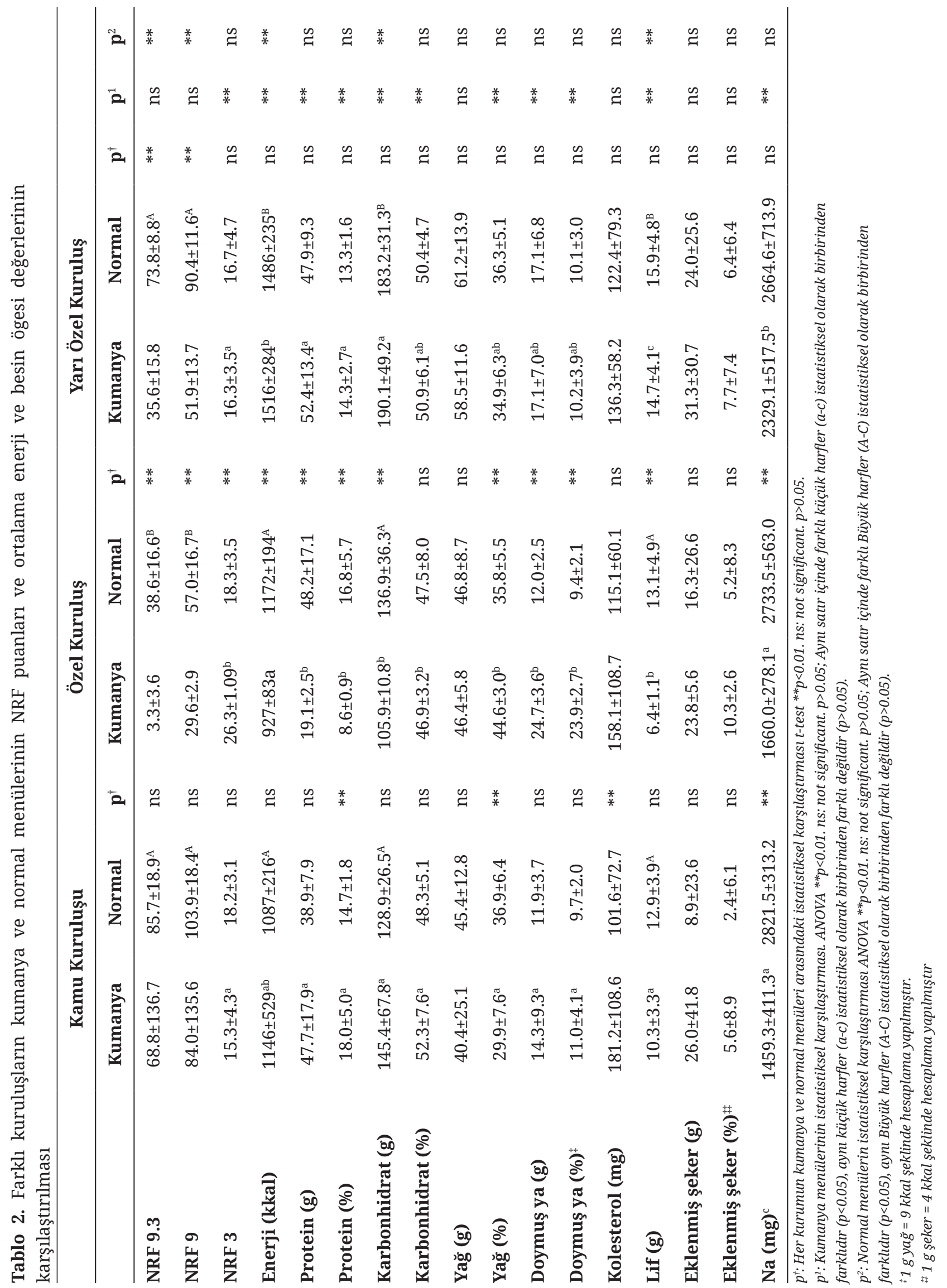




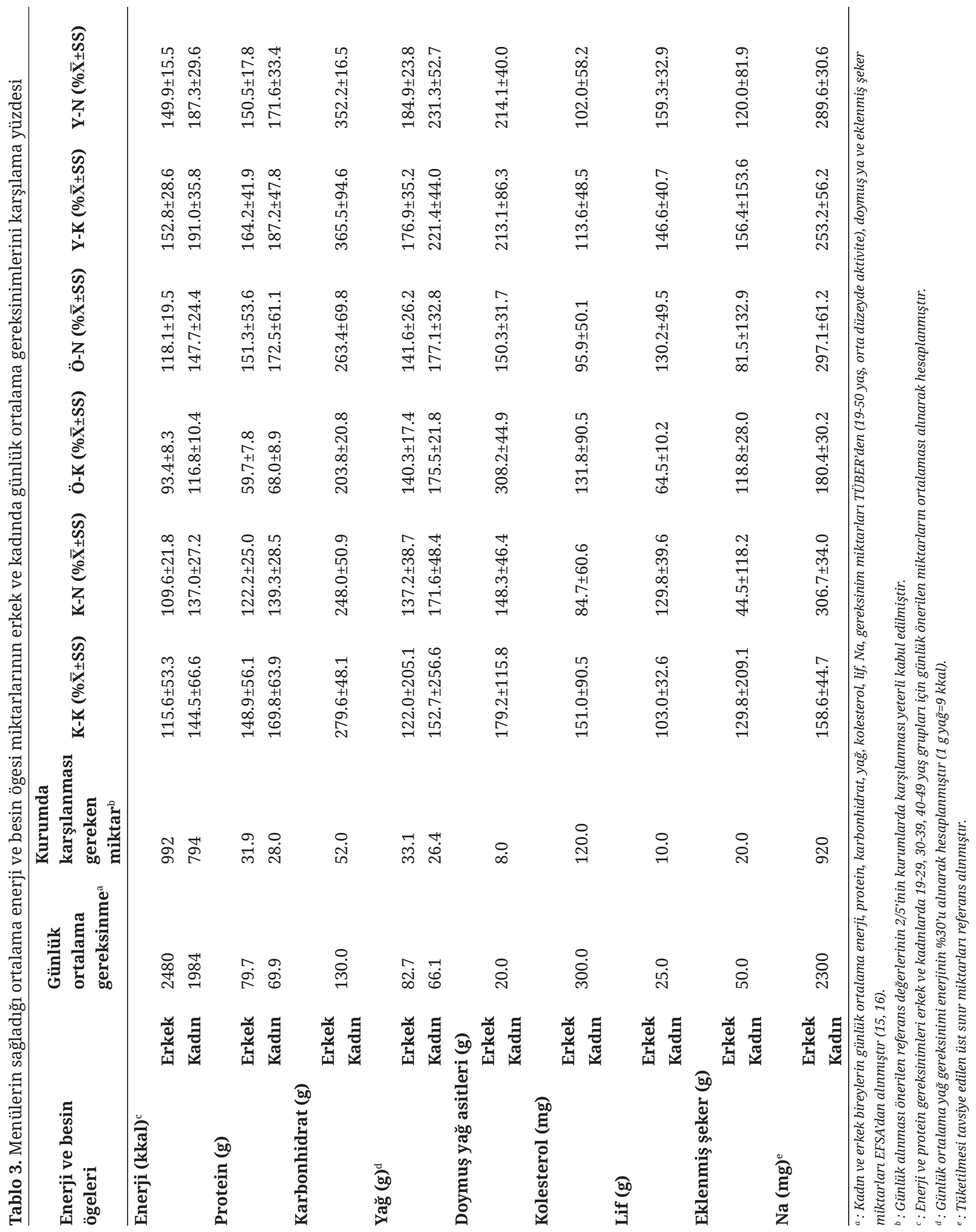




\section{TARTIŞMA}

$\mathrm{Bu}$ çalışmada, pandemi döneminde Ankara'da hizmet veren üç farklı özellikteki TBS’nin kumanya ve normal menülerinin incelenmesi amaçlanmış, menüler besin ögesi örüntü profili ve enerji ve besin ögesi içeriklerinin yeterlilikleri yönünden değerlendirilmiştir.

Kumanya yemek servisleri TBS hizmeti verilen grubun günlük enerji ve besin ögesi gereksinimlerinin karşılanması amacıyla ana veya ara öğün olarak servis edilebilen menülerdir. $\mathrm{Bu}$ menüler işçi yemekhanelerinde ve ceza evlerinde hizmet veren TBS'de düzenli olarak kullanılabildiği gibi tüm kurumlardaacildurumlardadaservisedilebilmektedir. $\mathrm{Bu}$ menülerde sıcak/soğuk sandviçler, kutu meyve sularl, ayran, süt, sebze ve kurubaklagil konserveleri, kuru meyveler, yağlı tohumlar, krakerler, kurabiyeler tercih edilebilmektedir (21). Kumanya menüleri hazırlanırken tüketicilerin beslenme alışkanlıkları, enerji ve besin ögesi gereksinimleri ve fizyolojik durumları göz önünde bulundurulmalı, yüksek besin ögesi içeriği, duyusal kalite ve besin güvenilirliği sağlanacak şekilde servis edilmelidir.

Yapılan çalışmalarda NRF puanının tüketicilerin daha sağlıklı besin tercihleri yapmasında ve diyet kalitesini geliştirmede yardımcı olabileceği, sebze ve meyveler ile süt ve süt ürünlerinin yüksek NRF puanına katkıda bulunurken, ultra işlenmiş besinler, kek, kurabiye, hamur işleri ve tatllların düşük NRF puanına katkıda bulunduğu belirtilmektedir (19,20,22-24). Bu çalışmada, NRF9.3 puanı en yüksek (85.7 \pm 18.9$)$ menü $\mathrm{K}-\mathrm{N}$, en düşük $(3.3 \pm 3.6)$ menü ise Ö-K olarak tespit edilmiştir. K-N dört kap set seçimsiz bir menüdür ve menülerde dört besin grubundan da besinlerin yer almasına, çeşitliliğin sağlanmasına ve verilme sıklığına dikkat edilmiştir. Ancak Ö-K yumurta, peynir, zeytin, simit, kek vb. kahvaltılıklar ile kısıtlı olduğundan besin ögesi içeriği sınırlı kalmıştır. Ayrıca Ö-K’nın NRF9 puanı en düşük (29.6 \pm 2.9$)$ ve NRF3 puanı en yüksek $(26.3 \pm 1.09)$ menü olduğu görülmüştür. Kamu ve yarı özel kuruluşun kumanya menüleri, normal menülerinin modifiye edilmiş şekli (ekmek arası tavuk/et döner gibi) iken özel kurumun kumanya ve normal menüleri arasında benzerlik bulunmamaktadır. Yukarıda da belirtildiği gibi Ö-K kahvaltı öğününe benzerken, Ö-N 4 kaptan oluşmaktadır. Dikmen ve Pekcan (2013)'ün yaptığı çalışmada tek öğün hizmet veren 5 üniversite yemekhanesinin bir aylık menülerinin NRF9.3 puanları ortalama -1.17-36.79 arasında tespit edilmiş, tüm menülerin kız öğrencilerin enerji ihtiyacını karşıladığı, erkek öğrencilerin enerji ihtiyacını ise sadece iki menünün karşıladığı belirtilmiştir. Ayrıca menülerde toplam yağ ve yağ yüzdesi ortalamasının yüksek, lif içeriği ortalamasının düşük ve menülerin bileşim olarak yetersiz olduğu bildirilmiştir. Sodyum içeriğinin hesaplamasında yemeğe eklenen tuzun sodyumu hariç tutulmuş ve ortalama 392.95-1499.94 mg tespit edilmiştir. Yazarlar ayrıca TBS'de menülerin sağlığı iyileştirici ve sağlıklı beslenmeyi geliştirici özelliklerde olması gerektiğini belirtmişlerdir (17). Benzer şekilde Ankara'da özel bir üniversite kafeteryasının bir aylık öğle yemeği menüsünün NRF9.3 puanları 0.09-3.19 arasında bulunmuş ve menülerin besin değeri ve çeşitliliğinin yiyecek seçiminde en önemli belirleyicilerden biri olduğu belirtilmiştir. Sonuç olarak araştırmacılar TBS'de sağlıklı menüler sunmanın önemine ve diyetisyen istihdamının gerekliliğine vurgu yapmışlardır (25).

Bu çalışmada kamu ve yarı özel kurumların normal ve kumanya menülerinin enerji içerikleri arasında fark görülmezken, Ö-K’nın enerji içeriğinin (927£83) Ö-N'den (1172 \pm 19$)$ düşük olduğu görülmüş, fakat günlük gereksinmenin iki cinsiyette de karşılandığı saptanmıştır. Kamu ve yarı özel kuruluşunda servis edilen menüler genel olarak enerji ve besin ögeleri gereksinimlerini karşılarken, menülerin yağ, doymuş y.a. ve Na içeriği önerilerin üzerinde bulunmuştur. Bu durumun TBS'de kullanılan standart tarifelerin yă ve tuz içeriklerinin yüksek olmasından kaynaklandığı düşünülmektedir.

Çalışmada, kumanya ve normal menülerin lifiçerikleri kamu ve yarı özel kuruluşlarda sunulan menülerde 
benzer bulunurken, Ö-K’nın lif içeriğinin Ö-N'den düşük olduğu görülmüştür. Ayrıca kamu ve yarı özel kuruluşların normal ve kumanya menülerinin tüketicilerin lif gereksinimlerini karşılama yönünden yeterli olduğu, özel kurumda ise normal menüler lif gereksinimini karşılarken, kumanya menülerinin lif içeriği $(6.4 \pm 1.1 \mathrm{~g})$ gereksinmenin 2/5'ini karşılama (\%64.5 \pm 10.2 ) yönünden yetersiz olduğu bulunmuştur. Ö-K’nın lif içeriğinin yarıdan fazlası menülerde bulunan zeytin ve domatesten karşılanmıştır. Bu durum Ö-K’nın besin çeşitliliği yönünden diğer menülerden zayıf olduğunu göstermektedir. Bağışıklık sistemi üzerine etkileri göz önünde bulundurulduğunda TBS'de servis edilen menülerin lif içeriğinin yeterli olması önem taşımakta, kumanya menüleri hazırlanırken de menü planlama ilkelerine uyulması gerekmektedir. Besin hijyeni açısından taze sebze ve meyve sunumum riskli olduğu zamanlarda menüler kurubaklagil, tam tahıllar vb. diğer lif kaynakları ile desteklenmelidir.

Araştırmalar, artan şeker tüketimi, günlük enerji alımının yüksek olması ve düşük fiziksel aktivite düzeylerinin COVID-19'a bağlı mortalite ile ilişkili olduğunu göstermektedir (26). Yüksek açlık kan glikozu ile hastaneye başvuran hastaların ciddi COVID-19 semptomları için artan risk altında olduğu bildirilmiş (27), yüksek glikoz seviyelerinin, in vitro SARS-CoV-2 viral yüklerinin artmasına neden olduğu rapor edilmiştir (26). Bu çalışmada K-K, Ö-K, Y-K ve Y-N'de eklenmiş şeker içeriğinin (sırasıyla 5.6 \pm 8.9 , $10.3 \pm 2.6,7.7 \pm 7.4,6.4 \pm 6.4$ g) kurumda alınması uygun olan üst sinırın (enerjinin \%5’i) üzerinde olduğu bulunmuştur. Menüler incelendiğinde K-K’da her gün paketli bir içecek (ayran, gazlı içecek, meyve suyu vb.) ve meyve ya da tatll (şekerpare, kadayıf vb.); Ö-K'da her gün eklenmiş şeker içerikli bir besin (hazır meyve suyu, kek vb.); Y-K'da ise her gün bir tatlı (muhallebi vb.) bulunmaktadır. Şekerin metabolik ve COVID-19 ile ilişkili etkileri göz önünde bulundurulduğunda menülerde tatlı ve şekerli içecek verilme sıklığının azaltılması ve bu besinler yerine meyve ve yağlı tohumlar gibi besinlerin eklenmesi ile eklenmiş şeker içeriklerinin azalması sağlanacaktır.
Yeterli ve dengeli beslenme, güçlü bağışıklık sistemi için önemli bir etkendir ve hem yetersiz beslenme hem de aşırı beslenme, bağışıklık yanıtını olumsuz etkileyebilmektedir. COVID-19'u önleyebilen veya iyileştirebilen tek bir besin ögesi veya besin için yeterli düzeyde kanıt olmamakla birlikte, yeterli, dengeli ve sağlıklı beslenmenin etkili olduğu ifade edilmektedir $(1,28)$.

Koronavirüs besinlerde çoğalmasa dahi besinlerin virüsün taşınmasında aracı olma potansiyeli nedeniyle pandemi döneminde güvenilir besinin üretilmesi ve tüketicilere ulaştırılabilmesi için besin endüstrisi ve TBS'de besin işleme, üretim, paketleme, servis ve dağıtım aşamalarında kontaminasyon riskini en aza düşürecek uygulamaların yer alması büyük önem taşımaktadır. Sağlık Bakanlığı'nın önermiş olduğu kumanya servisi uygulamasında besin çeşitliliğinin sağlanması için farklı yemek gruplarından seçeneklerin sunulabileceği tek kullanımlık servis gereçleri, paketli su ve ekmekler tercih edilmelidir. Bireylerin yeterli ve dengeli beslenmesine katkı sağlamada önemli bir rol oynaması nedeniyle TBS’de sunulan menülerin kumanya menüsü gibi farklı servis türleri dahil olmak üzere tüketicilerin enerji ve besin ögesi gereksinmelerini karşılayacak, bağışıklık sistemi fonksiyonlarını destekleyecek yüksek diyet kalitesinde olması gerekmektedir. $\mathrm{Bu}$ nedenle menülerin bu konuda eğitim almış, yeterli bilgi, beceri ve donanıma sahip, işin uzmanları tarafindan hazırlanması ve dolayısıyla kurumlarda diyetisyen istihdamının sağlanması büyük önem arz etmektedir.

Yazarlık katkısı - Author contributions: Çalışmanın tasarımi: SS, MK; Çalışma verilerinin elde edilmesi: SS, DG, GGT; Verilerin analiz edilmesi; SS, DG, GGT; Makale taslağının oluşturulması: SS, DG, GGT, MK; İ̧̧erik için eleştirel gözden geçirme: MK; Yayinlanacak versiyonun son onayl: SS, DG, GGT, MK. $\square$ Study design: SS, MK; Data collection: SS, DG, GGT; Data analysis: SS, DG, GGT; Draft preparation: SS, DG, GGT, MK; Critical review for content: MK; Final approval of the version to be published: SS, DG, GGT, MK.

Çıkar çatışması - Conflict of interest: Yazarlar çıkar çatışması olmadığını beyan ederler. - The authors declare that they have no conflict of interest. 


\section{KAYNAKLAR}

1. Moscatelli F, Sessa F, Valenzano A, Polito R, Monda V, Cibelli G, et al. COVID-19: Role of nutrition and supplementation. Nutrients. 2021;13(3):976.

2. Parthasarathy P, Vivekanandan S. An extensive study on the COVID-19 pandemic, an emerging global crisis: Risks, transmission, impacts and mitigation. J Infect Public Health. 2020;14(2):249-10.

3. Yllmaz SK, Eskici G. Evaluation of emotional (depression) and behavioral (nutritional, physical activity, sleep) status of Turkish adults during the COVID-19 pandemic period. Public Health Nutr. 2020;24(5):1-21.

4. T.C. İçişleri Bakanlığı. Koronavirüs Tedbirleri Konulu Ek Genelge. 2020. Erişim: https://www.icisleri.gov.tr/81il-valiligine-koronavirus-tedbirleri-konulu-ek-genelgegonderildi-08-09-20. Erişim tarihi: 11 Haziran 2021.

5. T.C.SağlıkBakanlığı.COVID-19Salgın Yönetimive Çalışma Rehberi Bilimsel Danışma Kurulu Çalışması. 1 Ekim 2020. Erişim: https://covid19.saglik.gov.tr/Eklenti/41415/0/ covid19-toplumdasalginyonetimirehberipdf.pdf Erişim tarihi: 11 Haziran 2021.

6. Erdem İ. Koronavirüse (COVID-19) karşı Türkiye'nin karantina ve tedbir politikaları. Turkish Studies. 2020;15(4):377-11.

7. Barman A, Das R, De PK. Impact of COVID-19 in food supply chain: Disruptions and recovery strategy. Current Research in Behavioral Sciences. 2021;2:100017.

8. Ayseli YI, Aytekin N, Buyukkayhan D, Aslan I, Ayseli MT. Food policy, nutrition and nutraceuticals in the prevention and management of COVID-19: Advice for healthcare professionals. Trends Food Sci Technol. 2020;105:186-13.

9. Wei CV, Chen H, Lee YM. Factors influencing customers' dine out intention during COVID-19 reopening period: The moderating role of country-of-origin effect. Int J Hosp Manag. 2021;95:102894.

10. Kim JJ, Kim I, Hwang J. A change of perceived innovativeness for contactless food delivery services using drones after the outbreak of COVID-19. Int J Hosp Manag. 2021;93:102758.

11. Fiori F, Bravo G, Parpinel G, Malavolta R, Lazzer S. Relationship between body mass index and physical fitness in Italian prepubertal schoolchildren. PLoS One. 2020;15(5):0233362.

12. Childs CE, Calder PC, Miles EA. Diet and immune function. Nutrients. 2019;11(8):1-9.
13. U.S. Food and Drug Administration (FDA). Menu Labeling Rule Key Facts for Industry. 2018, Available at: https://www.fda.gov/Food/GuidanceRegulation/ GuidanceDocumentsRegulatoryInformation/ LabelingNutrition/ucm515020.htm Accessed June 21, 2021.

14. Merdol TK. Toplu Beslenme Servisi Yapılan Kurumlar İçin Standart Yemek Tarifeleri. 2019, Ankara: Hatiboğlu Yayıncilık.

15. T.C. Sağlık Bakanlığı. Türkiye Beslenme Rehberi (TÜBER) 2015. Sağlık Bakanlığı Yayınları, Ankara, 2016.

16. European Food Safety Authority (EFSA). Review of labelling reference intake values-scientific opinion of the panel on dietetic products, nutrition and allergies on a request from the commission related to the review of labelling reference intake values for selected nutritional elements. EFSA J. 2009;7:1008.

17. Dikmen D, Pekcan G. Besin ögesi örüntü profili: Toplu beslenme hizmeti veren kuruluşlarda uygulanan menülerin değerlendirilmesi. Bes Diy Derg. 2013;41(3):234-7.

18. Drewnowski A. Defining nutrient density: Development and validation of the nutrient rich foods index. J Am Coll Nutr. 2009;28(4):421-5.

19. Hess JM, Slavin JL. Healthy snacks: Using nutrient profiling to evaluate the nutrient-density of common snacks in the United States. J Food Sci. 2017;82(9):2213-7.

20. Streppel MT, Sluik D, van Yperen JF, Geelen A, Hofman A, Franco OH, et al. Nutrient-rich foods, cardiovascular diseases and all-cause mortality: The Rotterdam study. Eur J Clin Nutr. 2014;68(6):741-6.

21. T.C. Sağlık Bakanlığı Halk Sağlığı Genel Müdürlüğü. Toplu Beslenme Sistemleri (Toplu Tüketim Yerleri) İçin Ulusal Menü Planlama ve Uygulama Rehberi, Sağlık Bakanlığı Yayınları, Ankara, 2020.

22. Gupta S, Hawk T, Aggarwal A, Drewnowski A. Characterizing ultra-processed foods by energy density, nutrient density, and cost. Front Nutr. 2019;6:70.

23. Glanz K, Hersey J, Cates S, Muth M, Creel D, Nicholls J, et al. Effect of a nutrient rich foods consumer education program: Results from the nutrition advice study. J Acad Nutr Diet. 2012;112(1):56-7.

24. Drewnowski A. The Nutrient Rich Foods Index helps to identify healthy, affordable foods. Am J Clin Nutr. 2010;91(4):1095-6. 
25. Kalyoncu ZB, Çetiner Ö, Balcı TN, Eroğlu ZB, KutluayMerdol T. Perspectives of healthy eating environment on campus: A qualitative study in a private university in Ankara, Turkey. Bes Diy Derg. 2020;48(3):18-20.

26. Chesnut WM, MacDonald S, Wambier CG. Could diet and exercise reduce risk of COVID-19 syndemic? Med Hypotheses. 2021;148:110502.
27. Lazarus G, Audrey J, Wangsaputra VK, Tamara A, Tahapary DL. High admission blood glucose is an independent risk factor of poor prognosis in COVID-19: A systematic review and dose-response meta-analysis. medRxiv. 2020.

28. Lange KW, Nakamura Y. Lifestyle factors in the prevention of COVID-19. Glob Health J. 2020;4(4):146-7. 
Ek 1. Kuruluşların sunmuş oldukları kumanya menülerinde servis edilen yemek ve besin gruplarından bazı örnekler

\begin{tabular}{|c|c|c|}
\hline Kamu Kuruluşu & Özel Kuruluş & Yarı Özel Yarı Kamu Kuruluşu \\
\hline \multirow{11}{*}{$\begin{array}{l}\text { - } \text { Ekmek Arası Sucuk } \\
\text { - Ekmek Arası Köfte (Garnitürle) } \\
\text { - Ekmek Arası Ciğer (Garnitürle) } \\
\text { - Tavuk Döner (Garnitürle) } \\
\text { - Lahmacun (Garnitürle) }\end{array}$} & - Siyah/Yeşil Zeytin & - Çorba \\
\hline & - Beyaz/Kaşar Peynir & - Tavuk Döner Sandviç \\
\hline & - Yumurta & - Dana Kavurma Sandviç \\
\hline & & - Misket Köfte \\
\hline & & - Kıymalı Pide \\
\hline & - Kek & \\
\hline & - Poğaça & \\
\hline & - Simit & \\
\hline & - Bisküvi & \\
\hline & - Çokokrem & \\
\hline & - Bal-Tereyağ & $\begin{array}{l}\text { - Pirinç Pilavı } \\
\text { - Salata }\end{array}$ \\
\hline - Ayran & - Domates & - Ayran \\
\hline $\begin{array}{l}\text { - Yoğurt } \\
\text { - Kola }\end{array}$ & - Salatalık & - Yoğurt \\
\hline - Meyve & - Meyve Suyu & - Meyve \\
\hline - Tatlı & & - Turşu \\
\hline
\end{tabular}

*Her satırda bulunan besinlerden bir tanesi bir öğünde servis edilmektedir. 